\title{
Application of the Microwave Technique in Continuous Flow Processing of Organophosphorus Chemical Reactions
}

\author{
Erika Bálint ${ }^{\mathbb{D}}$, Ádám Tajti® and György Keglevich * ${ }^{\mathbb{C}}$ \\ Department of Organic Chemistry and Technology, Budapest University of Technology and Economics, \\ 1521 Budapest, Hungary; ebalint@mail.bme.hu (E.B.); tajti.adam@mail.bme.hu (A.T.) \\ * Correspondence: gkeglevich@mail.bme.hu; Tel.: +36-1-463-5883
}

Received: 8 February 2019; Accepted: 1 March 2019; Published: 7 March 2019

\begin{abstract}
The microwave (MW) technique is an efficient tool in the realization of organic reactions, as well as in the analytical field and in the food industry. The continuous flow approach is of special interest as a promising way to scale-up MW-assisted syntheses. Besides summarizing the batch precedents, this review focuses on the utilization of the MW technique in the continuous-flow realization of organophosphorus transformations. The advantages of the continuous flow technique against the batch accomplishment are also shown. A few materials chemistry-related applications are also mentioned.
\end{abstract}

Keywords: microwave irradiation; microwave reactors; continuous flow technique; organophosphorus syntheses

\section{Introduction}

\subsection{Batch vs. Continuous Flow Systems}

Continuous procedures have been playing a significant role in important fields like the oil, plastic, and fine chemical industries, or metal processing for a long time [1]. The paradigm shift from batch reactions to continuous accomplishments is the consequence of progress in organic chemistry, and came to the front in the last decade [2].

As compared to a step-by-step batch reaction (Figure 1/I), where the most important parameters are the concentration of the starting materials, the temperature, and the reaction time, in continuous flow operations (Figure 1/II) the outcome can be controlled by the flow rate of the reagents and the average residence time set in the reactor. A continuous flow reaction can reach a steady state when the intake and the output are stationary. This means that the product is obtainable continuously in a permanent quality [3].

Flow reactors offer a basically different processing environment [4]. In a typical flow reactor, relatively small quantities are present in the reacting volume, allowing for a better mixing and a faster response on parameter adjustments. The precise parameter control is the key factor to obtain the target molecules with better purity and selectivity, as well as in higher yields. Continuous processes also mean an improvement regarding safety, as the handling of toxic or unstable intermediates becomes easier when smaller amounts are used [5]. Due to the low volume ratio and small quantities, the temperature regulation is simple, which makes the overall reaction safer. Moreover, flow reactors do not contain any gas volume, which enables reaction temperatures exceeding the boiling point of the solvent more easily. 


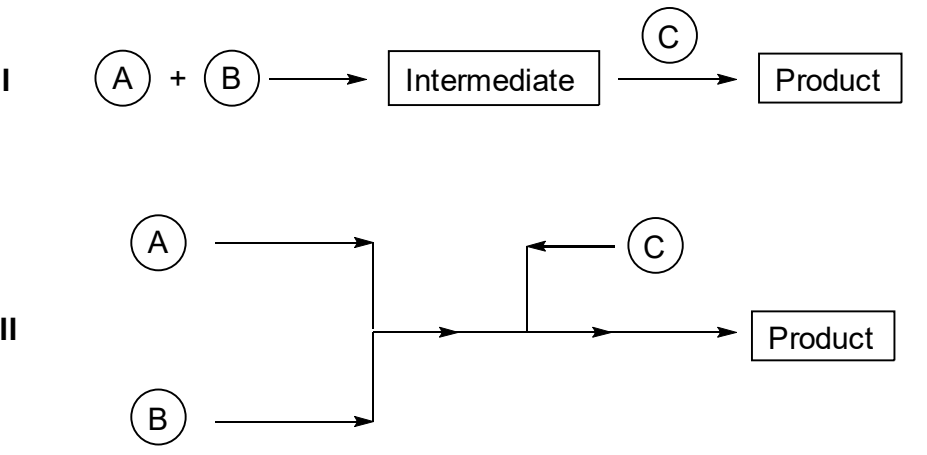

Figure 1. Schematic drawings of a batch and a continuous flow system.

An up-to-date and safe synthesis requires a fully controlled process [6]. Flow reactors can be readily coupled with tools of the process analytical technology (PAT), allowing real-time monitoring and the possibility for automation. Due to the easy monitoring and constant product quality, a continuous flow reactor can be an ideal choice for syntheses in the pharmaceutical industry [7].

The scale-up of flow reactions should be mentioned as a possible drawback [8]. This problem may be overcome by operating a series of parallel flow reactors of the same size. The flow reactions under discussion require a homogeneous medium with low viscosity, which may also mean a challenge in certain applications. The price of the necessary equipment for a continuous process is usually higher compared to that of a batch reactor [9].

\subsection{Batch Microwave Chemistry}

Microwave (MW) irradiation is widely used as a heat source in different fields, such as organic, inorganic, and analytical chemistry, finding applications in the medicinal, polymer, and food industries, as well as in the areas of material processing $[10,11]$.

The evolution of MW-assisted processes started in the 1950s [12]. For three decades, the MW technique was mainly used in the food industry or as a heat source for drying. The first chemistry-related applications, e.g., sample preparation and digestion in analytical chemistry, also appeared during this period. The first MW-assisted chemical syntheses were introduced in 1986 [13,14]. Since then, thousands of publications have been published in this area.

Early synthetic attempts using MW irradiation were carried out in kitchen MW ovens [12]. In these devices, the MW irradiation is controlled by turning on and off the magnetron, which does not allow continuous irradiation and makes the process uncontrollable. The lack of precise measurement and control of the most important parameters (temperature and pressure) makes these experiments unreproducible. The problem was recognized, and this initiated the development of professional MW reactors designed for laboratory use. The first commercially available MW reactors appeared on the market in the early 2000s. The improvement from household MW ovens was significant. These MW reactors were equipped with a specially designed MW cavity, a built-in magnetic stirrer, and a precise temperature sensor, and also offered a connection to a PC for the monitoring and control of the experiments. The use of professional MW chemistry became broadly available, and this multiplied the amount of publications in the area under discussion.

In contrast to conventional heat sources, MW can directly heat the molecules in the bulk of a mixture [15]. Besides the energy efficiency, MW heating has several other benefits, such as accelerating reactions and offering milder reaction conditions, higher yields, and better selectivities, as well as allowing solvent- and/or catalyst-free methods.

As the mechanism of MW heating requires the interaction of MWs and the material, the dielectric constants of the reagents have to be checked before designing a MW-assisted synthesis [10]. At least one of the starting materials should be polar enough to be able to absorb the MW energy. In certain 
cases, polar additives (e.g., polar catalysts, salts, or ionic liquids) may be added to increase the polarity of the mixture [16-18].

Over the years, the MW technique has proven to be efficient in a wide variety of syntheses. Among these, a few reaction types like couplings, multicomponent reactions, condensations, and cycloadditions turned out to be especially advantageous under MW conditions [19].

Although the MW technique has several benefits, the scale-up suffers from a serious limitation [12]. The MW irradiation is generated by a magnetron coil, which has a defined geometry. Structural materials, like borosilicate glass or Teflon, are needed for MW equipment requiring a special design, not allowing for the establishment of larger-scale reactors. Manufacturers of MW devices offer multimode reactors, where 6-12 samples can be heated parallelly. However, this is far away from a real scale-up, which is inevitable for industrial-like applications. A more suitable approach allowing MW-assisted syntheses in larger quantities is discussed in the next chapter.

\subsection{Continuous Flow Microwave Attempts}

According to a review in the field of MW-assisted material chemistry [20], continuous processes have been developed for the preparation of carbides, sintering of ceramics, or the continuous treatment of oil-contaminated drill cuttings. These instances differ from the usual flow reactions discussed in this subchapter, as the feed of the reactor is not a homogenous solution.

In MW-assisted organic chemistry, the continuous flow technique is of special interest. Combining MW heating with the continuous flow technique creates a promising way to scale-up MW-assisted syntheses [12,15,21-23]. The first systems coupling MWs and continuous flow were applied to polymer heating and solid drying in the 1980s [24,25]. The continuous flow MW reactors for chemical reactions appeared in the 1990s [26]. Since then, the number of publications in this field has been constantly increasing, and until the present more than 300 papers have been published. The advantages of continuous flow MW reactors were reported for a series of transformations. However, in many cases, fabricated domestic MW ovens were used. Due to the uncontrolled temperature and pressure in these non-professional MW "reactors", it is practically impossible to reproduce these transformations [23,27]. Gradually, professional MW-flow systems with accurate temperature measuring devices were also developed $[28,29]$.

The continuous flow MW systems usually consist of three main parts: the dispensing units for the starting reagents, the MW cavity, and the product collector (Figure 2). The reagents are fed into the reactor using one or more pumps that may be HPLC or syringe pumps. The pressure is usually controlled by a back-pressure regulator while the temperature is monitored using a built-in IR sensor or a fiber optic sensor. In most cases, the flow reactor is made of MW transparent Pyrex or Teflon. Further scale-up of flow MW systems can be realized by applying parallel reactors.

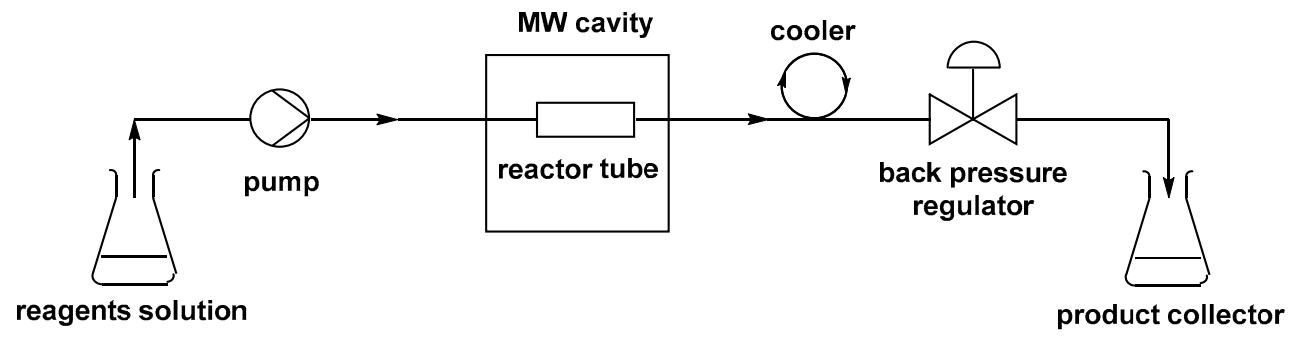

Figure 2. Schematic drawing of continuous flow microwave (MW) systems.

There are many types of continuous flow MW reactors [21], which contain a normal flask or tube [30], an $\Omega$ - or U-shaped tube [31,32], a spiral glass tube [30,33-35], or a mixed tube [36] to accommodate the reactive volume. Furthermore, reactor designs of fixed bed tubular coils [37,38], filled columns [37-39], and capillary reactors [40-42] are also available. Coupling MW heating and microreactors is also a challenging endeavour [23]. 
There are several papers, which reported on continuous flow MW accomplishments in the $\mathrm{g}$ or $\mathrm{kg}$ scales [27,43-57], or even larger scales (500 kg product per day) [58].

The spread of MW and continuous flow techniques have resulted in an enormous development in synthetic chemistry. Continuous flow MW reactors make possible efficient, fast, and selective transformations, as well as precise monitoring and control of the reaction parameters.

\subsection{Microwaves in Batch Organophosphorus Syntheses}

Guenin summarized the early results obtained in MW-promoted P-chemistry [55].

It was found by us that P-hydroxy phospholene oxides, -phospholane oxides, and -hexahydrophosphinine oxides (1) could be esterified with alcohols under MW conditions to provide the respective phosphinates (2) in yields of 31-82\% [56-60]. Although this protocol means a green way to prepare the phosphinates, the temperatures of $200-235{ }^{\circ} \mathrm{C}$ and the times of up to $5 \mathrm{~h}$ are disadvantageous. Later on, we observed that, in the presence of $10 \%$ of ionic liquids (ILs), the esterifications were more efficient. This was shown via the esterification of different ring phosphinic acids (1) with pentanol (Scheme 1). Among the imidazoliaun salts tested as catalysts, [bmim] $\left[\mathrm{PF}_{6}\right]$ was found to be the most appropriate [61]. The use of this additive made almost complete conversions possible, as well as higher yields (72-94\%) at lower temperatures of $180-220{ }^{\circ} \mathrm{C}$ after shorter reaction times of $0.5-2 \mathrm{~h}$. The positive effect of the IL additives is the consequence of their better MW absorbing ability.

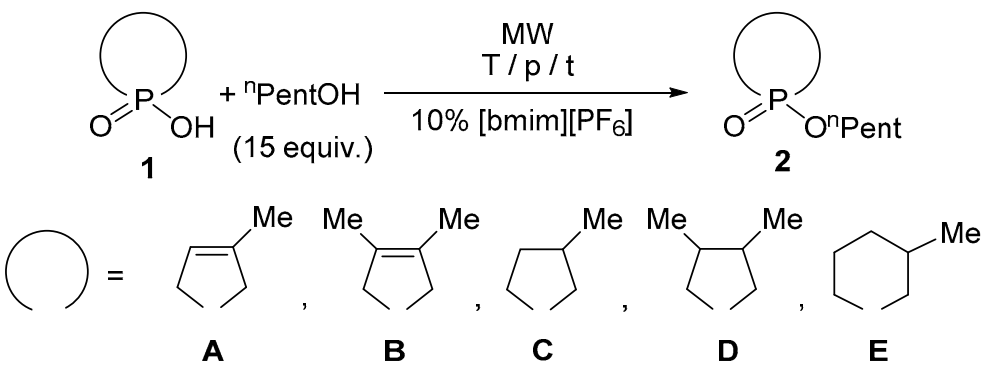

Scheme 1. Direct esterification of ring phosphinic acids (1) by pentanol using $[\mathrm{bmim}]\left[\mathrm{PF}_{6}\right]$ as the catalyst.

The solid-liquid heterogeneous phase alkylation of ring phosphinic acids (1) was studied by alkyl halides under MW irradiation, using $\mathrm{K}_{2} \mathrm{CO}_{3}$ to remove the liberated hydrogen halogenide (Scheme 2) [57,62]. The effect of triethylbenzylammonium chloride (TEBAC) as a phase transfer catalyst (PTC) was also investigated. In the cases of the alkylation of 1-hydroxy-3-phospholene oxides (1A or 1B), it was found that by using benzyl bromide, which is of increased reactivity, the respective phosphinates (3A and 3B) were obtained in yields of $92 \% / 84 \%$ (also in the absence of a catalyst). At the same time, when alkyl halides of normal ( ${ }^{n} \mathrm{Pr}$ - and ${ }^{n} \mathrm{Bu}$-bromide) or decreased reactivities ( ${ }^{i} \mathrm{Pr}$-bromide) were applied, the presence of TEBAC enhanced the reactions. Yields of $90-96 \%$ were obtained for derivatives with normal alkyl chains. In these cases, the effect of the catalyst was synergetic with the MWs. The alkylations were then extended to the esterification of 1-hydroxyphospholane oxides (1C and 1D) and a 1-hydroxy-hexahydrophosphinine oxide (1E). The respective esters were obtained in rather good yields (81-98\%).

Aryl phosphonates (5) may be intermediates for arylphosphonic acids. A MW-promoted, $\mathrm{NiCl}_{2}$-catalyzed Arbuzov reaction of aryl bromides (4) with triethyl phosphite was developed by our team (Scheme 3). In this case, a catalytic transformation was assisted by MWs [63,64]. 


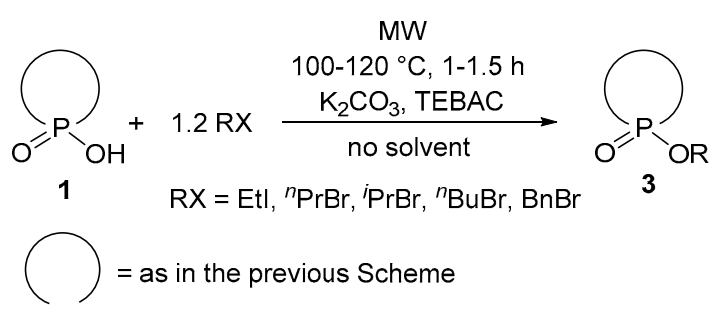

Scheme 2. The reaction of ring phosphinic acids (1) with alkyl halides.

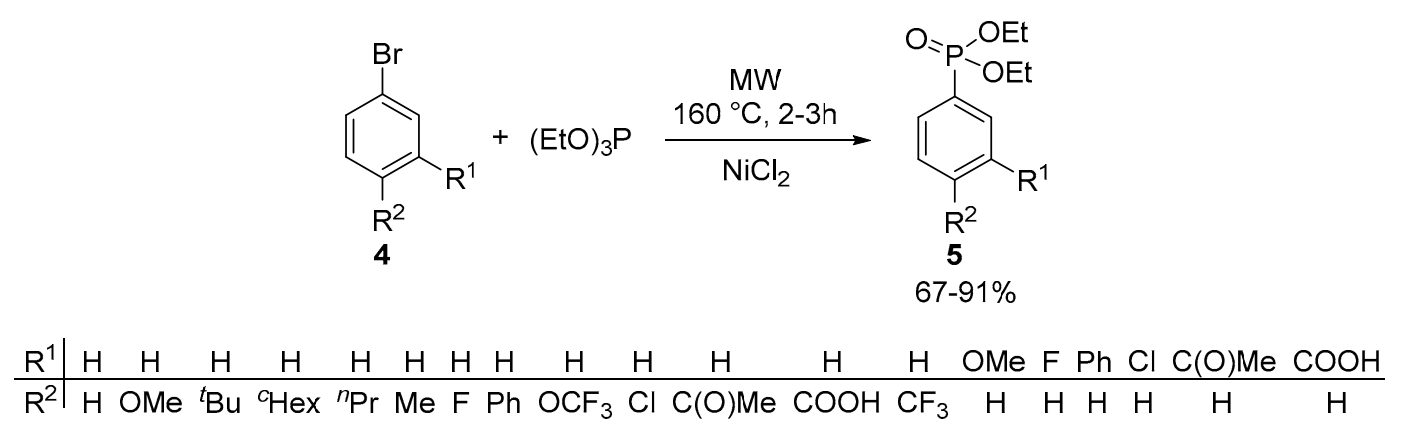

Scheme 3. Arbuzov reaction of aryl bromides and triethyl phosphite.

The solid-liquid phase alkylation of $\mathrm{CH}$ acidic $\mathrm{P}$-derivatives, such as diethyl cyanomethylphosphonate (6), diethyl ethoxycarbonylmethylphosphonate (7), and tetraethyl methylenebisphosphonate (8), providing products 9-11, was developed under MW irradiation (Scheme 4) [65-67]. There was no need to apply a PTC under MW irradiation [68,69]. A protocol for the di-substitution of diethyl ethoxycarbonylmethylphosphonate (7) was also worked out [70].

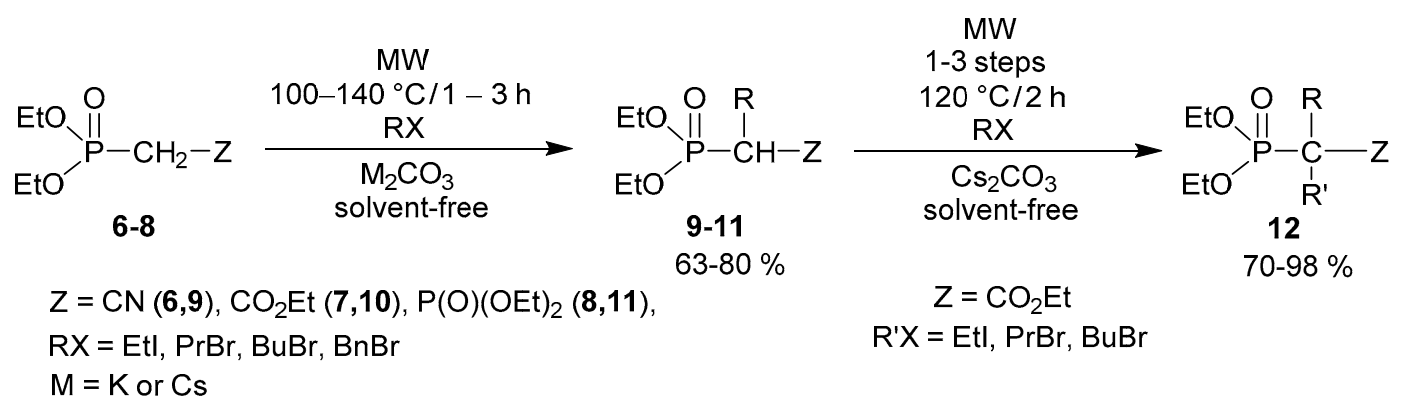

Scheme 4. Alkylation of active methylene-containing phosphonates.

It was found that there was no need for a catalyst in the Kabachnik-Fields reactions carried out under MW conditions [71,72]. A series of $\alpha$-aminophosphonate derivatives (13) was synthesized by the three-component reactions of primary or secondary amines, oxo-compounds, and different $>\mathrm{P}(\mathrm{O}) \mathrm{H}$ reagents, like dialkyl phosphites, alkyl phenyl- $H$-phosphinates, and secondary phosphine oxides (Scheme 5) [71-76].

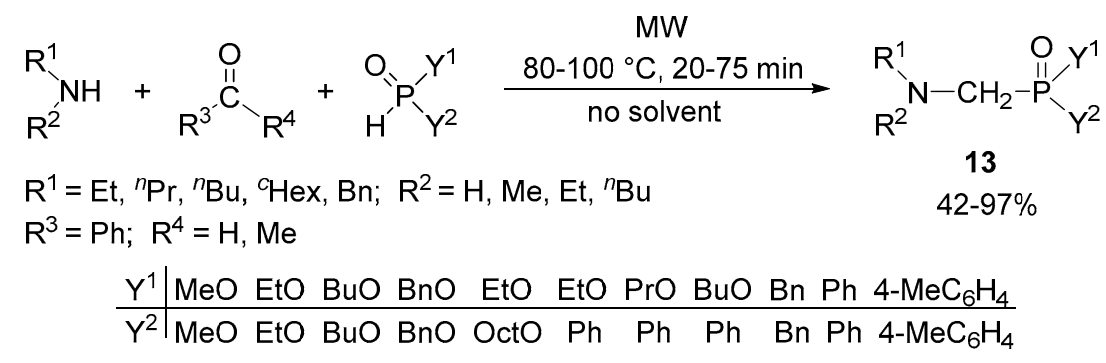

Scheme 5. Simple Kabachnik-Fields reaction. 
Double Kabachnik-Fields reactions were also developed, where the primary amines were reacted with two equivalents of paraformaldehyde and the same amounts of the $>\mathrm{P}(\mathrm{O}) \mathrm{H}$ species under MW irradiation in a catalyst-free manner (Scheme 6) [73-79]. The respective products (14) could be prepared in variable yields. After double deoxygenation of the bis(aminophosphine oxides) (14, $\mathrm{Y}^{1}=\mathrm{Y}^{2}=\mathrm{Bn}$, $\mathrm{Ph}$ or $4-\mathrm{MeC}_{6} \mathrm{H}_{4}$ ), the bisphosphines obtained were used as bidentate P-ligands in the preparation of ring Pt complexes [76-79].

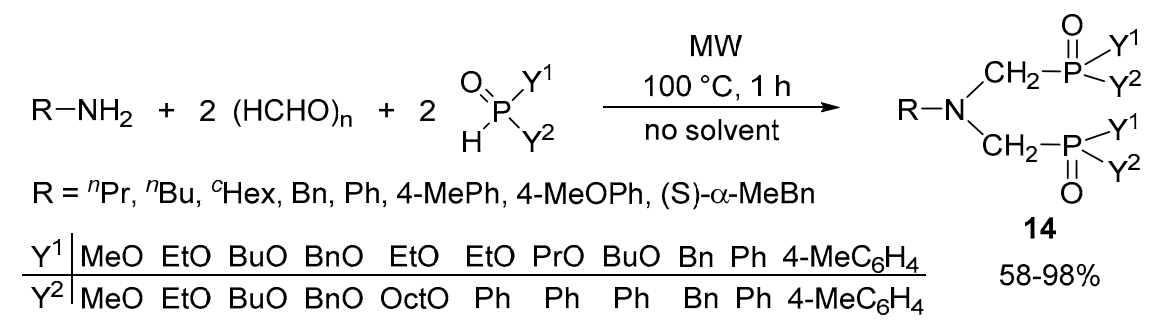

Scheme 6. Double Kabachnik-Fields reaction starting from primary amines.

The deoxygenation of phosphine oxide by-products is challenging. $\mathrm{Cl}_{3} \mathrm{SiH}$ or $\mathrm{PhSiH}_{3}$ are suitable reducing agents, however, the previous reagent is corrosive, while the latter one is expensive. In replacement of these reagents, the cheap $\left(\mathrm{Me}_{2} \mathrm{SiH}\right)_{2} \mathrm{O}$ (TMDS) and polymethylsiloxane $\left(-(\mathrm{OSiMeH})_{\mathrm{n}}-; \mathrm{PMHS}\right)$ were used under MW conditions. It was proved that under MW irradiation, there was no need for any catalyst proposed by Beller et al. [80]. This is exemplified by the reduction of 1-phenyl-3-methyl-3-phospholene 1-oxide (15) using $\mathrm{PhSiH}_{3}, \mathrm{TMDS}$ and PMHS, as summarized in Scheme 7 [81-84].

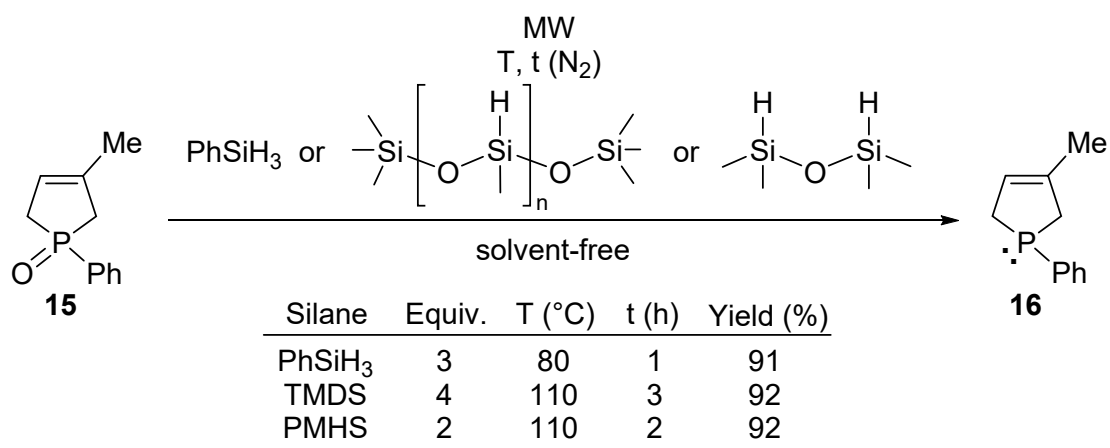

Scheme 7. Reduction of a 3-phospholene oxide by cheap silanes.

The first P-C coupling reaction between aryl- or vinyl-halides and dialkyl phosphites furnishing phosphonates was described by Hirao using $\mathrm{Pd}\left(\mathrm{PPh}_{3}\right)_{4}$ as the catalyst $[85,86]$. Later on, other methods were also reported to replace the $\mathrm{Pd}(0)$ catalyst with $\mathrm{Pd}(\mathrm{II})$ or another metal (e.g., $\mathrm{Ni}(\mathrm{II})$ salts applied together with mono- or bidentate P-ligands). The $\mathrm{P}-\mathrm{C}$ coupling was then extended by utilizing other $>\mathrm{P}(\mathrm{O}) \mathrm{H}$ reagents, bases, and solvents. Our research group found that the $\mathrm{P}-\mathrm{C}$ coupling of aryl-bromides and different $>\mathrm{P}(\mathrm{O}) \mathrm{H}$ species, like dialkyl phosphites, ethyl phenyl- $H$-phosphinate, and diphenylphosphine oxide may take place in the presence of $\mathrm{Pd}(\mathrm{OAc})_{2}$ as the catalyst precursor under MW conditions without the addition of the usual P-ligands, but using the P-reagent in some excess (Scheme 8 ) $[87,88]$. The $\operatorname{ArP}(\mathrm{O})<$ products $(\mathbf{1 7})$ were obtained in variable yields. Our idea was that the excess of the $>\mathrm{P}(\mathrm{O}) \mathrm{H}$ compounds existing under a tautomeric equilibrium (with the $>\mathrm{P}-\mathrm{OH}$ form) may act as P-ligands [89]. 


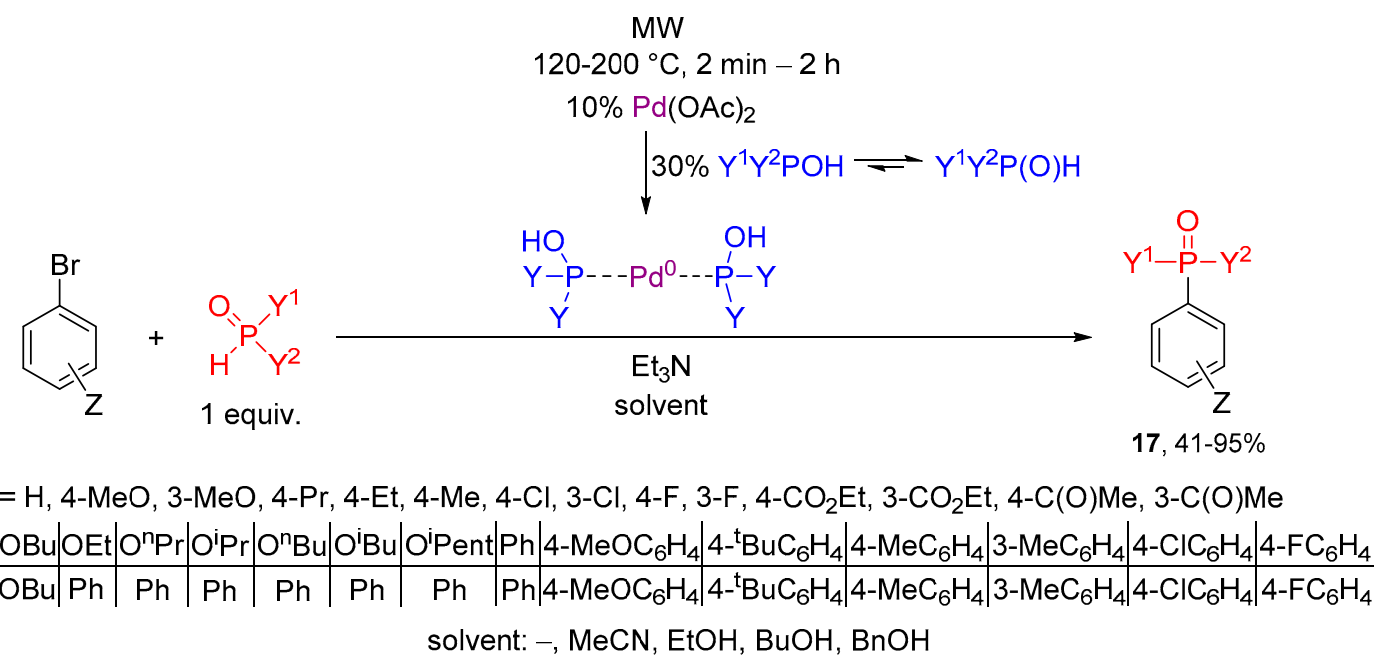

Scheme 8. The $\mathrm{P}-\mathrm{C}$ coupling reaction of bromobenzenes and $>\mathrm{P}(\mathrm{O}) \mathrm{H}$ reagents.

\section{Microwave-Assisted Continuous Flow Applications}

\subsection{Development of the Continuous Flow Microwave Device}

Among continuous flow MW-assisted syntheses, there are examples for esterifications [27,44,46], acylations [27,44,46], multicomponent [27] and rearrangement reactions [27,28,44], couplings [27,28,43,44], and polycondensations [90]. The simplest model is the esterification of carboxylic acids with alcohols, where different types of flow cells (e.g., teflon coils, glass tubes, or ceramic tubes) were applied in kitchen MW ovens [91,92] or in professional MW reactors [93,94].

A continuous flow MW system (Figure 2, Section 1.3) was developed by us, using a commercially avialable flow cell (Figure 3) immersed into a $\mathrm{CEM}^{\circledR} \mathrm{MW}$ reactor [95]. The mixture of the reagents is fed into the reactor by a HPLC pump. The temperature of the mixture is monitored and controlled by an IR sensor built into the reactor. After irradiation at the desired temperature, the leaving reaction mixture is cooled down in a spiral-like cooler, and is passed through a back pressure regulator operating at 250 PSI.

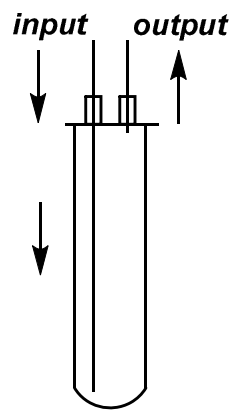

Figure 3. Sketch of the continuous flow cell.

The first model reaction to be investigated by us in the flow system developed was the direct esterification of benzoic acid with various aliphatic alcohols [95]. At first, batch reactions were carried out to investigate the reaction. The reactivity of the alcohols towards benzoic acid was mapped and the parameters were optimized. Based on the batch results, the esterification rate of benzoic acid depends on the boiling point (from EtOH to ${ }^{n} \mathrm{PentOH}$ ) and the steric properties of the alcohols ( ${ }^{n} \mathrm{Pr}$ vs ${ }^{i} \mathrm{Pr}$ ). Then, the esterifications were optimized further in the continuous flow MW reactor. It was found that when using 15 equivalents of alcohol at $140{ }^{\circ} \mathrm{C}$ at a flow rate of $0.35-0.25 \mathrm{~mL} / \mathrm{min}$ (with a residence time of 20-30 $\mathrm{min}$ ), the direct esterifications were complete and the corresponding alkyl benzoates were obtained in yields of $95-98 \%$. 


\subsection{Elaboration of the Continuous Flow Transesterification of Dialkyl Phosphites}

The MW-assisted transesterification of dialkyl phosphites (dialkyl H-phosphonates) was studied with simple alcohols (Scheme 9) under catalyst-free conditions [96]. These compounds may serve as starting materials, for example in the Kabachnik-Fields condensations or in the aza-Pudovik reactions, to provide potentially bioactive $\alpha$-aminophosphonates [97]. As the first step, the transesterifications were performed under batch conditions. It was found that, depending on the conditions (molar ratio, temperature, and reaction time), the alcoholysis of dialkyl phosphites (18) resulted in the formation of dialkyl phosphites with two different (19) or with two identical (20) alkyl groups in different ratios. Dialkyl phosphites with two different alkyl groups (19) are valuable building-blocks in the synthesis of chiral organophosphorus derivatives [73].

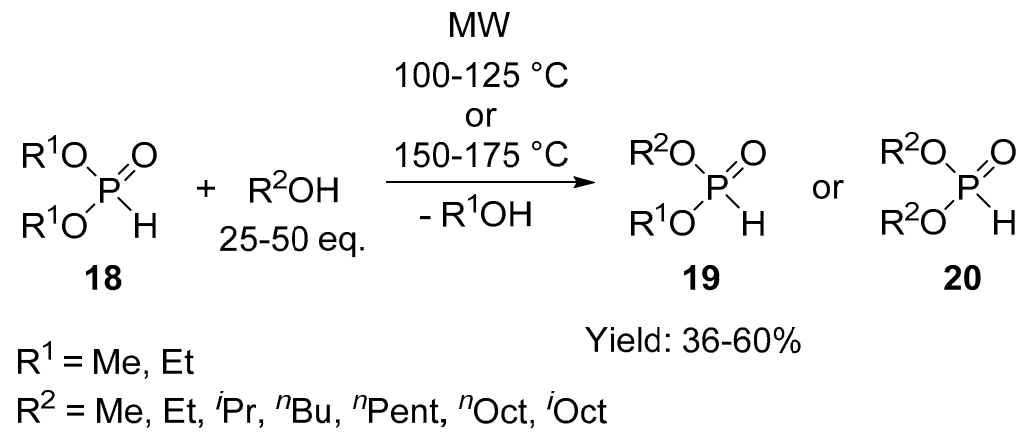

Scheme 9. Batch alcoholysis of dialkyl phosphites by simple alcohols.

Hydroxyalkyl- or aminoalkyl-functionalized $H$-phosphonates could be synthesized by the alcoholysis of dialkyl phosphites with glycols or amino alcohols (Scheme 10) [98,99]. During the investigation of this reaction, it was found that mixed phosphites (21) and/or fully transesterified products (22) were formed as major components, depending on the ratio of the starting materials, the temperature, and the reaction time. These derivatives may be starting materials in the synthesis of P-containing polymers, which form a special group within plastics $[100,101]$. In certain cases, a small amount of by-products (23-25) was also present in the reaction.

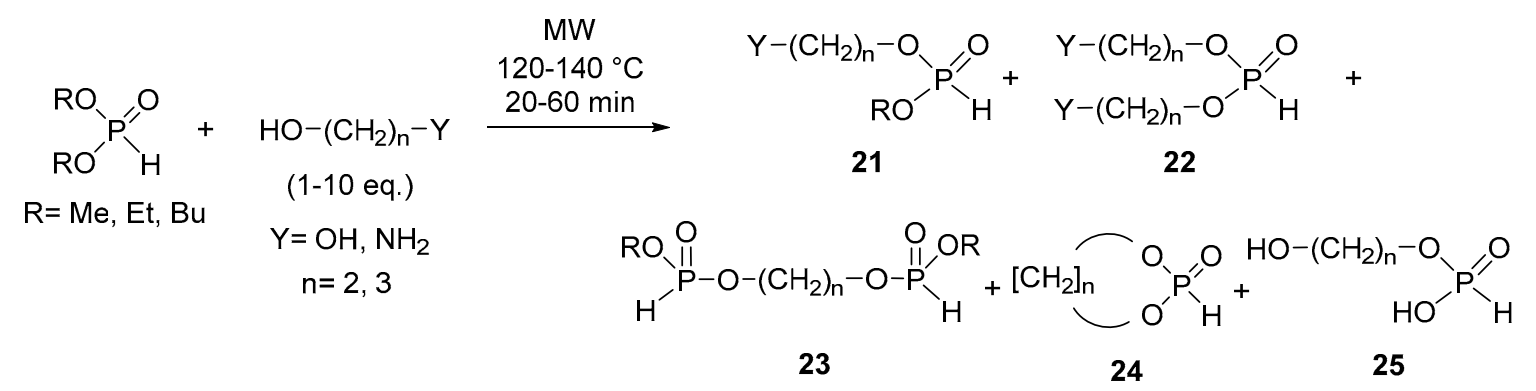

Scheme 10. Batch alcoholysis of dialkyl phosphites by diols and aminoalcohols.

The continuous flow alcoholysis of dialkyl phosphites by aliphatic alcohols in the absence of catalyst was also elaborated using the same continuous flow MW system applied in the esterification of benzoic acid (Scheme 11) [102]. By the precise control of the reaction parameters, the alcoholysis could be fine-tuned towards dialkyl phosphites with two different (19) or with two identical alkyl groups (20). Although the selectivity of the reaction was rather similar under flow and batch conditions, in the continuous flow reactor, the dialkyl phosphites with two different alkyl groups were obtained at a shorter reaction time in a higher proportion with a somewhat higher productivity. 


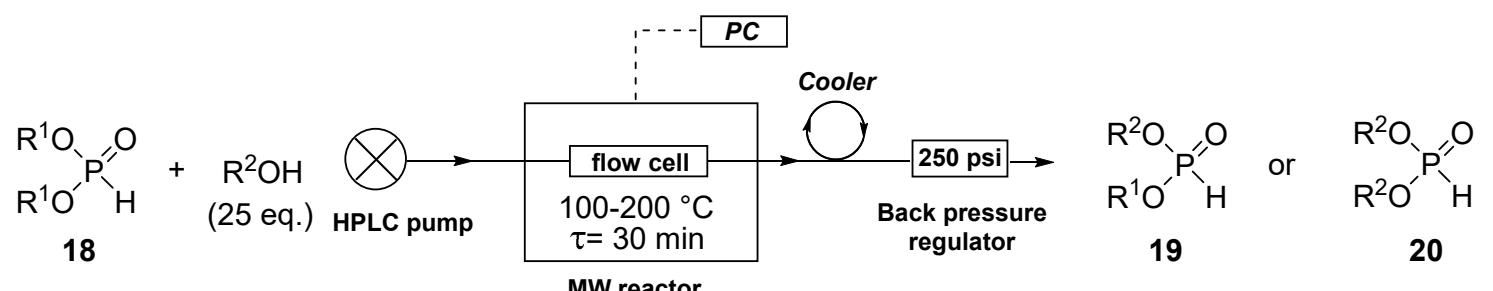

$\mathrm{R}^{1}=\mathrm{Me}, \mathrm{Et}$

Yield: $36-51 \%$

Yield: $77-88 \%$

$\mathrm{R}^{2}={ }^{i} \mathrm{Pr},{ }^{n} \mathrm{Bu},{ }^{i} \mathrm{Bu},{ }^{n} \mathrm{Pent}$

Scheme 11. Continuous flow MW system for the alcoholysis of dialkyl phosphites.

\subsection{Continuous Flow Synthesis of $\alpha$-Aminophosphonates by the aza-Pudovik Reaction}

We elaborated the MW-assisted continuous flow synthesis of potentially biologically active $\alpha$-aminophosphonates by the aza-Pudovik reaction, involving the addition of dialkyl phosphites to the $\mathrm{C}=\mathrm{N}$ double bond of imines (Scheme 12) [103]. Before optimization, we carried out the flow-compatible addition based on our previous experiences [104]. In this simple two-component model reaction, the reagents were fed together into the flow cell. The MW-assisted catalyst-free continuous flow reaction of $\mathrm{N}$-benzylidene-butylamine or $\mathrm{N}$-benzylidene-cyclohexylamine and diethyl phosphite in ethanol afforded the corresponding $\alpha$-aminophosphonates (26) in yields of $90-92 \%$.

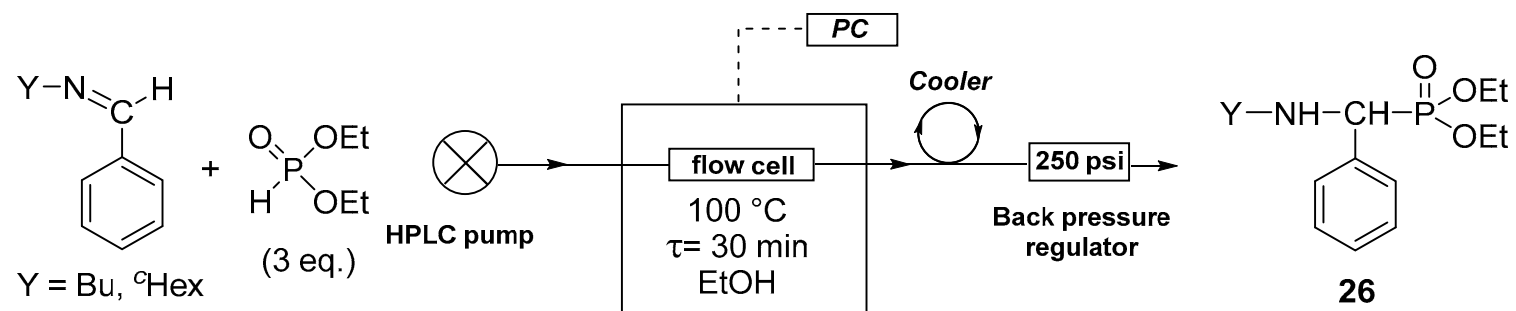

Yield: $90-92 \%$

Scheme 12. Continuous flow synthesis of $\alpha$-aminophosphonates by the aza-Pudovik reaction.

\subsection{The Synthesis of $\alpha$-Aminophosphonates by Continuous Flow Kabachnik-Fields Reaction}

An efficient synthetic route towards $\alpha$-aryl- $\alpha$-aminophosphonates is the three-component Kabachnik-Fields reaction of primary amines, benzaldehyde derivatives, and dialkyl phosphites. The continuous flow variation was elaborated by us (Scheme 13) [103]. To avoid the possible side reactions of the starting materials at room temperature resulting in the formation of an imine or an $\alpha$-hydroxyphosphonate, a dual-pump continuous flow system had to be developed. The mixtures of the primary amine and diethyl phosphite in ethanol (pump A), and benzaldehyde in ethanol (pump B) were fed separately into the mixer of the HPLC pump. After optimization of the conditions, the continuous flow method was proved to be more efficient than the batch approach, as the corresponding $\alpha$-aminophosphonates (27) were obtained in a shorter reaction time, and a lower excess of phosphite was needed. 


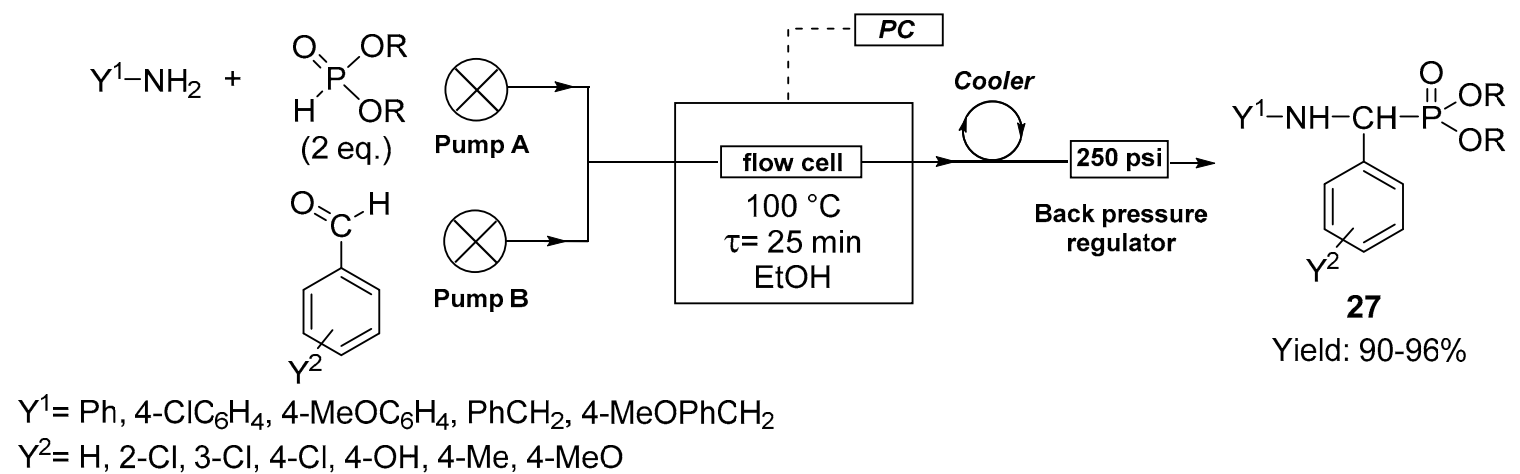

Scheme 13. Continuous flow synthesis of $\alpha$-aminophosphonates by the Kabachnik-Fields reaction.

\section{Conclusions}

The recent paradigm shift from batch processes to continuous flow operations has brought about a significant change in organic chemistry, and meant a challenge in organophosphorus chemistry. The continuous flow technique means improvements in respect to safety, selectivity, and efficiency, and makes possible the development of automated syntheses more easily. MW chemistry has come to the front in the 1980s. Since then, the MW technique has spread in various fields, including organic, analytical, and material chemistry. Many types of reactions were proved to be more efficient under MW conditions. In the field of organophosphorus chemistry, several transformations, such as the esterification of phosphinic acids, O- and C-alkylations, Kabachnik-Fields condensation, the reduction of phosphine oxides, and $\mathrm{P}-\mathrm{C}$ couplings all take advantage of MW irradiation. By combining flow chemistry and the MW technique, besides the benefits mentioned above, the easy scale-up of MW-assisted reactions has also become possible. The elaboration of the alcoholysis of dialkyl phosphites and the synthesis of $\alpha$-aminophosphonates by aza-Pudovik reactions, as well as Kabachnik-Fields reactions in a continuous flow MW reactor, allowed the preparation of the target organophosphorus products more efficiently, meaning an improved productivity as compared to the batch approaches.

Author Contributions: G.K., E.B. and Á.T. wrote the paper.

Funding: The project was supported by the Hungarian Research Development and Innovation Fund (K119202 and FK123961), by the National Research, Development and Innovation Fund of Hungary in the frame of the FIEK_16-1-2016-0007 (Higher Education and Industrial Cooperation Center) project. E.B. was supported by the János Bolyai Research Scholarship of the Hungarian Academy of Sciences (BO/00278/17/7), and by the ÚNKP-18-4-BME-131 New National Excellence Program of the Ministry of Human Capacities. Á.T. was supported by the ÚNKP-18-3-III-BME-251 New National Excellence Program of the Ministry of Human Capacities.

Conflicts of Interest: The authors declare no conflict of interest.

\section{References}

1. Ullmann's Encyclopedia of Industrial Chemistry, 7th ed.; Wiley-VCH: Weinheim, Germany, 2000; ISBN 978-3-527-30385-4.

2. Plutschack, M.B.; Pieber, B.; Gilmore, K.; Seeberger, P.H. The Hitchhiker's guide to flow chemistry. Chem. Rev. 2017, 117, 11796-11893. [CrossRef] [PubMed]

3. Glasnov, T. Continuous-Flow Chemistry in the Research Laboratory; Springer International Publishing: Basel, Switzerland, 2016; ISBN 978-3-319-32194-3.

4. Vaccaro, L. Sustainable Flow Chemistry: Methods and Applications; Wiley: Weinheim, Germany, 2017; ISBN 978-3-527-338528.

5. Movsisyan, M.; Delbeke, E.I.P.; Berton, J.K.E.T.; Battiloccihio, C.; Ley, S.V.; Stevens, C.V. Taming hazardous chemistry by continuous flow technology. Chem. Soc. Rev. 2016, 45, 4892-4928. [CrossRef] [PubMed]

6. Bakeev, K.A. Process Analytical Technology: Spectroscopic Tools and Implemented Strategies for the Chemical and Pharmaceutical Industries; Wiley-VCH: Chichester, UK, 2010; ISBN 978-0-470-72207-7. 
7. May, S.A. Flow Chemistry, Continuous Processing, and Continuous Manufacturing: A Pharmaceutical Perspective. J. Flow Chem. 2017, 7, 137-145. [CrossRef]

8. Strying, P.; Parracho, A.I.R. From discovery to production: Scale-out of continuous flow meso reactors. Beilstein J. Org. Chem. 2009, 5, 29. [CrossRef] [PubMed]

9. Pashkova, A.; Greiner, L. Towards Small-Scale Continuous Chemical Production: Technology Gaps and Challenges. Chem. Ing. Tech. 2011, 83, 1337-1342. [CrossRef]

10. Cravotto, G.; Carnaroglio, D. Microwave Chemistry; De Gruyter: Berlin, Germany, 2017; ISBN 978-3-11-047993-5.

11. Horikoshi, S.; Schiffmann, R.F.; Fukushima, J.; Serpone, N. Microwave Chemical and Materials Processing; Springer: Singapore, 2018; ISBN 978-981-10-6465-4.

12. Bálint, E.; Keglevich, G. The Spread of the Application of the Microwave Technique in Organic Synthesis. In Milestones in Microwave Chemistry; Keglevich, G., Ed.; Springer: Cham, Switzerland, 2016; pp. 1-10.

13. Gedye, R.; Smith, F.; Westaway, K.; Ali, H.; Baldisera, L.; Laberge, L.; Rousell, J. The use of microwave ovens for rapid organic synthesis. Tetrahedron Lett. 1986, 27, 279-282. [CrossRef]

14. Giguere, R.J.; Bray, T.L.; Duncan, S.M.; Majetich, G. Application of commercial microwave ovens to organic synthesis. Tetrahedron Lett. 1986, 27, 4945-4948. [CrossRef]

15. Kappe, C.O.; Stadler, A.; Dallinger, D. Microwaves in Organic and Medicinal Chemistry, 2nd ed.; Wiley: Weinheim, Germany, 2012; Volume 52, ISBN 978-3-527-33185-7.

16. Zhao, X.; Zhang, Z.; Wang, L.; Xi, K.; Cao, Q.; Wang, D.; Yang, Y.; Du, Y. Excellent microwave absorption property of Graphene-coated Fe nanocomposites. Sci. Rep. 2013, 3, 3421. [CrossRef] [PubMed]

17. Guo, H.; Yang, J.; Pu, B.; Chen, H.; Li, Y.; Wang, Z.; Niu, X. Excellent microwave absorption of lead halide perovskites with high stability. J. Mater. Chem. C 2018, 6, 4201-4207. [CrossRef]

18. Gong, J.; Yang, F.; Shao, Q.; He, X.; Zhang, X.; Liu, S.; Tang, L.; Deng, Y. Microwave absorption performance of methylimidazolium ionic liquids: Towards novel ultra-wideband metamaterial absorbers. RSC Adv. 2017, 7, 41980-41988. [CrossRef]

19. Kiss, N.Z.; Bálint, E.; Keglevich, G. Microwave-Assisted Syntheses in Organic Chemistry. In Milestones in Microwave Chemistry; Keglevich, G., Ed.; Springer: Cham, Switzerland, 2016; pp. 11-45.

20. Kitchen, H.J.; Vallance, S.R.; Kennedy, J.L.; Tapia-Ruiz, N.; Carassiti, L.; Harrison, A.; Whittaker, A.G.; Drysdale, T.D.; Kingman, S.W.; Gregory, D.H. Modern Microwave Methods in Solid-State Inorganic Materials Chemistry: From Fundamentals to Manufacturing. Chem. Rev. 2014, 114, 1170-1206. [CrossRef] [PubMed]

21. Keglevich, G.; Sallay, P.; Greiner, I. Continuous flow microwave reactors. Hung. Chem. J. 2008, 63, $278-283$.

22. de la Hoz, A.; Díaz-Ortiz, A. Nonconventional Techniques in Sustainable Flow Chemistry. In Sustainable Flow Chemistry: Methods and Applications; Vaccaro, L., Ed.; Wiley: Weinheim, Germany, 2017; pp. $219-248$.

23. Estel, L.; Poux, M.; Benamara, N.; Polaert, I. Continuous flow-microwave reactor: Where are we? Chem. Eng. Process. 2016, 113, 56-64. [CrossRef]

24. Wang, C.S. Processing parameters of continuous microwave heating of ethylene-propylene terpolymer. Rubber Chem. Technol. 1984, 57, 134-144. [CrossRef]

25. Gunasekaran, S. Grain drying using continuous and pulsed microwave energy. Dry. Technol. 1990, 8, $1039-1047$. [CrossRef]

26. Strauss, C.R. A Strategic, 'Green' Approach to Organic Chemistry with Microwave Assistance and Predictive Yield Optimization as Core, Enabling Technologies. Aust. J. Chem. 1999, 52, 83-96. [CrossRef]

27. Baxendale, I.; Hayward, J.; Ley, S. Microwave reactions under continuous flow conditions. Comb. Chem. High Throughput Screen. 2007, 10, 802-836. [CrossRef] [PubMed]

28. Öhrngren, P.; Fardost, A.; Russo, F.; Schanche, J.-S.; Fagrell, M.; Larhed, M. Evaluation of a nonresonant microwave applicator for continuous-flow chemistry applications. Org. Proc. Res. Dev. 2012, 16, 1053-1063. [CrossRef]

29. Rydfjord, J.; Svensson, F.; Fagrell, M.; Savmarker, J.; Thulin, M.; Larhed, M. Temperature measurements with two different IR sensors in a continuous-flow microwave heated system. Beilstein J. Org. Chem. 2013, 9, 2079-2087. [CrossRef] [PubMed]

30. Bonaccorsi, L.; Proverbio, E. Influence of process parameters in microwave continuous synthesis of zeolite LTA. Microporous Mesoporous Mater. 2008, 112, 481-493. [CrossRef]

31. Khadilkar, B.M.; Madyar, V.R. Scaling up of dihydropyridine ester synthesis by using aqueous hydrotrope solutions in a continuous microwave reactor. Org. Process Res. Dev. 2001, 5, 452-455. [CrossRef] 
32. Pillai, U.R.; Sahle-Demessie, E.; Varma, R.S. Hydrodechlorination of chlorinated benzenes in a continuous microwave reactor. Green Chem. 2004, 6, 295-298. [CrossRef]

33. Correa, R.; Gonzalez, G.; Dougar, V. Emulsion polymerization in a microwave reactor. Polymer 1998, 39, 1471-1474. [CrossRef]

34. Cáceres, A.; Jaimes, M.; Chávez, G.; Bravo, B.; Ysambertt, F.; Márquez, N. Continuous system with microwave irradiation to obtain alkyl benzoates. Talanta 2005, 68, 359-364. [CrossRef] [PubMed]

35. Vámosi, P.; Matsuo, K.; Masuda, T.; Sato, K.; Narumi, T.; Takeda, K.; Mase, N. (2018) Rapid Optimization of Reaction Conditions Based on Comprehensive Reaction Analysis Using a Continuous Flow Microwave Reactor. Chem. Rec. 2018, 18, 1-9. [CrossRef]

36. Bonnet, C.; Estel, L.; Ledoux, A.; Mazari, B.; Louis, A. Study of the thermal repartition in a microwave reactor: Application to the nitrobenzene hydrogenation. Chem. Eng. Proc. 2004, 43, 1435-1440. [CrossRef]

37. Bo, L.; Quan, X.; Chen, S.; Zhao, H.; Zhao, Y. Degradation of p-nitrophenol in aqueous solution by microwave assisted oxidation process through a granular activated carbon fixed bed. Water Res. 2006, 40, 3061-3068. [CrossRef] [PubMed]

38. Bagley, M.C.; Jenkins, R.L.; Lubinu, M.C.; Mason, C.; Wood, R. A simple continuous flow microwave reactor. J. Org. Chem. 2005, 70, 7003-7006. [CrossRef] [PubMed]

39. Kabza, K.G.; Chapados, B.R.; Getswicki, J.; McGrath, J.L. Microwave-induced esterification using heterogeneous acid catalyst in a low dielectric constant medium. J. Org. Chem. 2000, 65, 1210-1214. [CrossRef] [PubMed]

40. He, P.; Haswell, S.J.; Fletcher, P.D.I. Efficiency, monitoring and control of microwave heating within a continuous flow capillary reactor. Sens. Actuator B Chem. 2005, 105, 516-520. [CrossRef]

41. Shore, G.; Morin, S.; Organ, M.G. Catalysis in capillaries by Pd thin films using microwave-assisted continuous-flow organic synthesis (MACOS). Angew. Chem. Int. Ed. 2006, 45, 2761-2766. [CrossRef] [PubMed]

42. Comer, E.; Organ, M.G. A microreactor for microwave-assisted capillary (continuous flow) organic synthesis (MACOS). J. Am. Chem. Soc. 2005, 127, 8160-8167. [CrossRef] [PubMed]

43. Singh, B.K.; Kaval, N.; Tomar, S.; Van der Eycken, E.; Parmar, V.S. Transition metal-catalyzed carbon-carbon bond formation Suzuki, Heck, and Sonogashira reactions using microwave and microtechnology. Org. Process Res. Dev. 2008, 12, 468-474. [CrossRef]

44. Glasnov, T.N.; Kappe, C.O. Microwave-assisted synthesis under continuous-flow conditions. Macromol. Rapid Commun. 2007, 28, 395-410. [CrossRef]

45. Ullah, F.; Samarakoon, T.; Rolfe, A.; Kurtz, R.D.; Hanson, P.R.; Organ, M.G. Scaling out by microwave-assisted, continuous flow organic synthesis (MACOS): Multi-gram synthesis of bromo- and fluoro-benzofused sultams benzthiaoxazepine-1,1-dioxides. Chem. Eur. J. 2010, 16, 10959-10962. [CrossRef] [PubMed]

46. Dressen, M.H.C.L.; van de Kruijs, B.H.P.; Meuldijk, J.; Vekemans, J.A.J.M.; Hulshof, L.A. Flow processing of microwave-assisted (heterogeneous) organic reactions. Org. Process Res. Dev. 2010, 14, 351-361. [CrossRef]

47. Bergamelli, F.; Iannelli, M.; Marafie, J.A.; Moseley, J.D. A commercial continuous flow microwave reactor evaluated for scale-up. Org. Process Res. Dev. 2010, 14, 926-930. [CrossRef]

48. Bagley, M.C.; Fusillo, V.; Jenkins, R.L.; Lubinu, M.C.; Mason, C. Continuous flow processing from microreactors to mesoscale: The Bohlmann-Rahtz cyclodehydration reaction. Org. Biomol. Chem. 2010, 8, 2245-2251. [CrossRef] [PubMed]

49. Moseley, J.D.; Lawton, S.J. Initial results from a commercial continuous flow microwave reactor for scale-up. Chem. Today 2007, 25, 16-19.

50. Benaskar, F.; Hessel, V.; Krtschil, U.; Löb, P.; Stark, A. Intensification of the capillary-based Kolbe-Schmitt synthesis from resorcinol by reactive ionic liquids, microwave heating or a combination thereof. Org. Process Res. Dev. 2009, 13, 970-982. [CrossRef]

51. Leadbeater, N.E.; Barnard, T.M.; Stencel, L.M. Batch and continuous-flow preparation of biodiesel derived from butanol and facilitated by microwave heating. Energy Fuels 2008, 22, 2005-2008. [CrossRef]

52. Smith, C.J.; Iglesias-Siguenza, F.J.; Baxendale, I.R.; Ley, S.V. Flow and batch mode focused microwave synthesis of 5-amino-4-cyanopyrazoles and their further conversion to 4-aminopyrazolopyrimidines. Org. Biomol. Chem. 2007, 5, 2758-2761. [CrossRef] [PubMed] 
53. Organ, M.G.; Hanson, P.R.; Rolfe, A.; Samarakoon, T.B.; Ullah, F. Accessing stereochemically rich sultams via microwave-assisted, continuous flow organic synthesis (MACOS) scale-out. J. Flow Chem. 2011, 1, 32-39. [CrossRef] [PubMed]

54. Morschhäuser, R.; Krull, M.; Kayser, C.; Boberski, C.; Bierbaum, R.; Püschner, P.A.; Glasnov, T.N.; Kappe, C.O. Microwave-assisted continuous flow synthesis on industrial scale. Green Process Synth. 2012, 1, 281-290. [CrossRef]

55. Guenin, E.; Meziane, D. Microwave Assisted Phosphorus Organic Chemistry: A Review. Curr. Org. Chem. 2011, 15, 3465-3485. [CrossRef]

56. Kiss, N.Z.; Ludányi, K.; Drahos, L.; Keglevich, G. Novel Synthesis of Phosphinates by the MicrowaveAssisted Esterification of Phosphinic Acids. Synth. Commun. 2009, 39, 2392-2404. [CrossRef]

57. Keglevich, G.; Bálint, E.; Kiss, N.Z.; Jablonkai, E.; Hegedûs, L.; Grün, A.; Greiner, I. Microwave-Assisted Esterification of Phosphinic Acids. Curr. Org. Chem. 2011, 15, 1802-1810. [CrossRef]

58. Keglevich, G.; Kiss, N.Z.; Mucsi, Z.; Körtvélyesi, T. Insights into a surprising reaction: The microwaveassisted direct esterification of phosphinic acids. Org. Biomol. Chem. 2012, 10, 2011-2018. [CrossRef] [PubMed]

59. Kiss, N.Z.; Böttger, É.; Drahos, L.; Keglevich, G. Microwave-assisted direct esterification of cyclic phosphinic acids. Heteroat. Chem. 2013, 24, 283-288. [CrossRef]

60. Mucsi, Z.; Kiss, N.Z.; Keglevich, G. A quantum chemical study on the mechanism and energetics of the direct esterification, thioesterification and amidation of 1-hydroxy-3-methyl-3-phospholene 1-oxide. RSC Adv. 2014, 4, 11948-11954. [CrossRef]

61. Kiss, N.Z.; Keglevich, G. Microwave-assisted direct esterification of cyclic phosphinic acids in the presence of ionic liquids. Tetrahedron Lett. 2016, 57, 971-974. [CrossRef]

62. Bálint, E.; Jablonkai, E.; Bálint, M.; Keglevich, G. Alkylating esterification of 1-hydroxy-3-phospholene oxides under solventless MW conditions. Heteroat. Chem. 2010, 21, 211-214. [CrossRef]

63. Keglevich, G.; Grün, A.; Bölcskei, A.; Drahos, L.; Kraszni, M.; Balogh, G.T. Synthesis and proton dissociation properties of arylphosphonates: A microwave-assisted catalytic arbuzov reaction with aryl bromides. Heteroat. Chem. 2012, 23, 574-582. [CrossRef]

64. Dargó, G.; Bölcskei, A.; Grün, A.; Béni, S.; Szántó, Z.; Lopata, A.; Keglevich, G.; Balogh, G.T. Proton dissociation properties of arylphosphonates: Determination of accurate Hammett equation parameters. J. Pharm. Biomed. Anal. 2017, 143, 101-109. [CrossRef] [PubMed]

65. Greiner, I.; Grün, A.; Ludányi, K.; Keglevich, G. Solid-liquid two-phase alkylation of tetraethyl methylenebisphosphonate under microwave irradiation. Heteroat. Chem. 2011, 22, 11-14. [CrossRef]

66. Keglevich, G.; Grün, A.; Blastik, Z.; Greiner, I. Solid-liquid phase alkylation of P=O-functionalized CH acidic compounds utilizing phase transfer catalysis and microwave irradiation. Heteroat. Chem. 2011, 22, 174-179. [CrossRef]

67. Grün, A.; Blastik, Z.; Drahos, L.; Keglevich, G. Microwave-assisted alkylation of diethyl ethoxycarbonylmethylphosphonate under solventless conditions. Heteroat. Chem. 2012, 23, 241-246. [CrossRef]

68. Keglevich, G.; Grün, A. Microwave Irradiation as a Substitute for Phase Transfer Catalyst in CAlkylation Reactions. Curr. Green Chem. 2015, 2, 254-263. [CrossRef]

69. Grün, A.; Bálint, E.; Keglevich, G. Solid-Liquid Phase C-Alkylation of Active Methylene Containing Compounds under Microwave Conditions. Catalysts 2015, 5, 634-652. [CrossRef]

70. Grün, A.; Blastik, Z.; Drahos, L.; Keglevich, G. Dialkylation of diethyl ethoxycarbonylmethylphosphonate under microwave and solventless conditions. Heteroat. Chem. 2014, 25, 107-113. [CrossRef]

71. Keglevich, G.; Szekrényi, A. Eco-Friendly Accomplishment of the Extended Kabachnik-Fields Reaction; a Solvent- and Catalyst-Free Microwave-Assisted Synthesis of $\alpha$-Aminophosphonates and $\alpha$-Aminophosphine Oxides. Lett. Org. Chem. 2008, 5, 616-622. [CrossRef]

72. Keglevich, G.; Bálint, E. The Kabachnik-Fields Reaction: Mechanism and Synthetic Use. Molecules 2012, 17, 12821-12835. [CrossRef] [PubMed]

73. Tajti, Á.; Bálint, E.; Keglevich, G. Synthesis of ethyl octyl $\alpha$-aminophosphonate derivatives. Curr. Org. Synth. 2016, 13, 638-645. [CrossRef] 
74. Bálint, E.; Tóth, R.E.; Keglevich, G. Synthesis of alkyl $\alpha$-aminomethyl-phenylphosphinates and $N, N$-bis(alkoxyphenylphosphinylmethyl)amines by the microwave-assisted Kabachnik-Fields reaction. Heteroat. Chem. 2016, 27, 323-335. [CrossRef]

75. Bálint, E.; Tajti, Á.; Kalocsai, D.; Mátravölgyi, B.; Karaghiosoff, K.; Czugler, M.; Keglevich, G. Synthesis and utilization of optically active $\alpha$-aminophosphonate derivatives by Kabachnik-Fields reaction. Tetrahedron 2017, 73, 5659-5667. [CrossRef]

76. Bálint, E.; Tripolszky, A.; Jablonkai, E.; Karaghiosoff, K.; Czugler, M.; Mucsi, Z.; Kollár, L.; Pongrácz, P.; Keglevich, G. Synthesis and use of $\alpha$-aminophosphine oxides and $N, N$-bis(phosphinoylmethyl)amines-A study on the related ring platinum complexes. J. Organomet. Chem. 2016, 801, 111-121. [CrossRef]

77. Keglevich, G.; Szekrényi, A.; Szöllősy, Á.; Drahos, L. Synthesis of bis(phosphonatomethyl)-, bis(phosphinatomethyl)-, and bis(phosphinoxidomethyl)amines, as well as related ring bis(phosphine) platinum complexes. Synth. Commun. 2011, 41, 2265-2272. [CrossRef]

78. Bálint, E.; Fazekas, E.; Pintér, G.; Szöllősy, Á.; Holczbauer, T.; Czugler, M.; Drahos, L.; Körtvélyesi, T.; Keglevich, G. Synthesis and utilization of the bis $(>\mathrm{P}(\mathrm{O}) \mathrm{CH} 2)$ amine derivatives obtained by the double Kabachnik-Fields reaction with cyclohexylamine; Quantum chemical and X-ray study of the related bidentate chelate platinum complexes. Curr. Org. Chem. 2012, 16, 547-554. [CrossRef]

79. Bálint, E.; Fazekas, E.; Pongrácz, P.; Kollár, L.; Drahos, L.; Holczbauer, T.; Czugler, M.; Keglevich, G. N-Benzyl and $N$-aryl bis(phospha-Mannich adducts): Synthesis and catalytic activity of the related bidentate chelate platinum complexes in hydroformylation. J. Organomet. Chem. 2012, 717, 75-82. [CrossRef]

80. Li, Y.H.; Das, S.; Zhou, S.L.; Junge, K.; Beller, M. General and Selective Copper-Catalyzed Reduction of Tertiary and Secondary Phosphine Oxides: Convenient Synthesis of Phosphines. J. Am. Chem. Soc. 2012, 134, 9727-9732. [CrossRef] [PubMed]

81. Kovács, T.; Keglevich, G. The reduction of tertiary phosphine oxides by silanes. Curr. Org. Chem. 2017, 21, 569-585. [CrossRef]

82. Keglevich, G.; Kovács, T.; Csatlós, F. The deoxygenation of phosphine oxides under green chemical conditions. Heteroat. Chem. 2015, 26, 199-205. [CrossRef]

83. Kovács, T.; Urbanics, A.; Csatlós, F.; Binder, J.; Falk, A.; Uhlig, F.; Keglevich, G. A Study on the Deoxygenation of Phosphine Oxides by Different Silane Derivatives. Curr. Org. Synth. 2016, 13, 148-153. [CrossRef]

84. Kovács, T.; Urbanics, A.; Csatlós, F.; Keglevich, G. A study on the deoxygenation of trialkyl-, dialkyl-phenyland alkyl-diphenyl phosphine oxides by hydrosilanes. Heteroat. Chem. 2017, 28, e21376. [CrossRef]

85. Hirao, T.; Masunaga, T.; Yamada, N.; Ohshiro, Y.; Agawa, T. Palladium-catalyzed New Carbon-Phosphorus Bond Formation. Bull. Chem. Soc. Jpn. 1982, 55, 909-913. [CrossRef]

86. Hirao, T.; Masunaga, T.; Ohshiro, Y.; Agawa, T. A Novel Synthesis of Dialkyl Arenephosphonates. Synthesis 1981, 1981, 56-57. [CrossRef]

87. Jablonkai, E.; Keglevich, G. P-ligand-free, microwave-assisted variation of the Hirao reaction under solvent-free conditions; The $\mathrm{P}-\mathrm{C}$ coupling reaction of $>\mathrm{p}(\mathrm{O}) \mathrm{H}$ species and bromoarenes. Tetrahedron Lett. 2013, 54, 4185-4188. [CrossRef]

88. Keglevich, G.; Jablonkai, E.; Balázs, L.B. A "green" variation of the Hirao reaction: The P-C coupling of diethyl phosphite, alkyl phenyl- $H$-phosphinates and secondary phosphine oxides with bromoarenes using a P-ligand-free $\mathrm{Pd}(\mathrm{OAc})_{2}$ catalyst under microwave and solvent-free conditions. RSC Adv. 2014, 4, 22808-22816. [CrossRef]

89. Keglevich, G.; Henyecz, R.; Mucsi, Z.; Kiss, N.Z. The Palladium Acetate-Catalyzed Microwave-Assisted Hirao Reaction without an Added Phosphorus Ligand as a "Green" Protocol: A Quantum Chemical Study on the Mechanism. Adv. Synth. Catal. 2017, 359, 4322-4331. [CrossRef] [PubMed]

90. Ergan, B.T.; Bayaromoglu, M. Poly (L-lactic acid) synthesis using continuous microwave irradiationsimultaneous cooling method. Chem. Eng. Commun. 2018, 205, 1665-1677. [CrossRef]

91. Chen, S.-T.; Chiou, S.-H.; Wang, K.-T. Preparative scale organic synthesis using a kitchen microwave oven. J. Chem. Soc. Chem. Commun. 1990, 807-809. [CrossRef]

92. Pipus, G.; Plazl, I.; Koloini, T. Esterification of benzoic acid in microwave tubular flow reactor. Chem. Eng. J. 2000, 76, 239-245. [CrossRef]

93. Cablewski, T.; Faux, A.F.; Strauss, C.R. Development and Application of a Continuous Microwave Reactor for Organic Synthesis. J. Org. Chem. 1994, 59, 3408-3412. [CrossRef] 
94. Krull, M.; Moschhaeuser, R. Continuous Method for Producing Esters of Aromatic Carboxylic Acids. U.S. Patent 0088918, 12 April 2012.

95. Tajti, Á.; Tóth, N.; Bálint, E.; Keglevich, G. Esterification of benzoic acid in a continuous flow microwave reactor. J. Flow Chem. 2018, 8, 11-19. [CrossRef]

96. Bálint, E.; Tajti, Á.; Drahos, L.; Ilia, G.; Keglevich, G. Alcoholysis of dialkyl phosphites under Microwave conditions. Curr. Org. Chem. 2013, 17, 555-562. [CrossRef]

97. Bálint, E.; Tripolszky, A.; Tajti, Á. Synthesis of $\alpha$-aminophosphonates by the Kabachnik-Fields reaction. In Organophosphorus Chemistry; Keglevich, G., Ed.; De Gruyter: Berlin, Germany, 2018; pp. 108-147.

98. Keglevich, G.; Bálint, E.; Tajti, Á.; Mátravölgyi, B.; Balogh, G.T.; Bálint, M.; Ilia, G. Microwave-assisted alcoholysis of dialkyl phosphites by ethylene glycol and ethanolamine. Pure Appl. Chem. 2014, 86, 1723-1728. [CrossRef]

99. Tajti, Á.; Keglevich, G.; Bálint, E. Microwave-assisted alcoholysis of dialkyl H-phosphonates by diols and amino alcohols. Phosphorus Sulfur Silicon Relat. Elem. 2017, 192, 769-775. [CrossRef]

100. Wang, Y.-C.; Yuan, Y.-Y.; Du, J.-Z.; Yang, X.-Z.; Wang, J. Recent Progress in Polyphosphoesters: From Controlled Synthesis to Biomedical Applications. Macromol. Biosci. 2009, 9, 1154-1164. [CrossRef] [PubMed]

101. Troev, K.D. Polyphosphoesters: Chemistry and Application; Elsevier: Oxford, UK, 2012.

102. Bálint, E.; Tajti, Á.; Tóth, N.; Keglevich, G. Continuous Flow Alcoholysis of Dialkyl H-Phosphonates with Aliphatic Alcohols. Molecules 2018, 23, 1618. [CrossRef] [PubMed]

103. Bálint, E.; Tajti, Á.; Ladányi-Pára, K.; Tóth, N.; Mátravölgyi, B.; Keglevich, G. Continuous flow synthesis of $\alpha$-aryl- $\alpha$-aminophosphonates. Pure Appl. Chem. 2019, 91, 67-76. [CrossRef]

104. Bálint, E.; Tajti, Á.; Ádám, A.; Csontos, I.; Karaghiosoff, K.; Czugler, M.; Ábrányi-Balogh, P.; Keglevich, $\mathrm{G}$. The synthesis of $\alpha$-aryl- $\alpha$-aminophosphonates and $\alpha$-aryl- $\alpha$-aminophosphine oxides by the microwave-assisted Pudovik reaction. Beilstein J. Org. Chem. 2017, 13, 76-86. [CrossRef] [PubMed]

(C) 2019 by the authors. Licensee MDPI, Basel, Switzerland. This article is an open access article distributed under the terms and conditions of the Creative Commons Attribution (CC BY) license (http:// creativecommons.org/licenses/by/4.0/). 